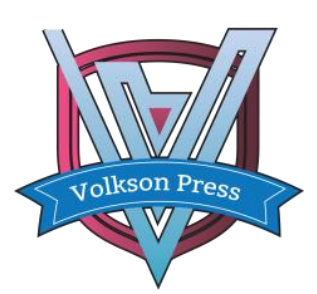

Contents List available at VOLKSON PRESS

Economics \& Management Innovations(EMI)

DOI : http://doi.org/10.26480/icemi.01.2017.392.394

\title{
Development Strategies of Chinese Financial Regulation in the Context of Integration of International Risks
}

\author{
Chao-Feng Hsu ${ }^{1,2}$, Chun-Hung Chen', Bi-Ru Lee ${ }^{2}$ \\ ${ }^{1}$ Zhou Enlai School of Government, Nankai University, Tianjin300071, China \\ 2Zhongshan Institute, University of Electronic Science and Technology of China, Guangdong 528402,China \\ visonhsu8989@126.com, easonda@163.com, maggen_lee@hotmail.com \\ This is an open access article distributed under the Creative Commons Attribution License, which permits unrestricted use, distribution, and reproduction in any \\ medium, provided the original work is properly cited.
}

\section{ARTICLE DETAILS}

\section{Article History:}

Received 02 october 2017

Accepted 06 october 2017

Available online 11 october 2017

\section{Keywords:}

financial regulation, subprime

mortgage crisis, risk integration,

the Third Basel Accord,

$\begin{array}{ccc}\text { maximization } & \text { of } & \text { profits. }\end{array}$

\section{ABSTRACT}

The U.S.-led international financial regulation and risk management in the past were inextricably linked to economic development in the past. In particular, after the "subprime mortgage crisis" in 2008, the United States and Europe have transmitted economic damages and influences at different levels to Asia, demonstrating the characteristics of integration of international risks and contributing to the establishment of risk regulation act of the "Third Basel Accord". In contrast, Chinese recent economic development has attracted worldwide attention, making China the world's second largest economy. In the context of current new international regulatory system, China shall find its own position in order to maximize profits.

\section{Introduction}

Financial regulations refer to the financial regulation and control over financial institutions by a government or authority, including market access, business scope, internal risk control, and so on. Financial regulation is often seen as a constant. Regulation has seldom been linked to the operation and risk management of a financial institution, such as the bankruptcy of Bahrain Bank and global economic turmoil and risk caused by RMBS. When subprime mortgage crisis occurred, the shares of RMBS (residential mortgage insurance) and HEL (house mortgage) held by the Bank of America against GDP rose from 7\% in 2004 to $18 \%$ in 2007. The growth of asset securitization commodities during the period was several times as much as the loans themselves and finally led to the crisis ${ }^{1-2}$.

Financial innovation can help financial institutions to bypass regulation and obtain potential benefits or avoid the risks of market uncertainty and decline in profits. Particularly, in terms of the banking-oriented financial product innovation, because the off-balance sheet businesses have no impact on the asset structure, under the indicators of current assetliability ratio and capital adequacy ratio, off-balance sheet product and service innovation emerges in endlessly. Financial innovation has three main contents, that is, securitization, off-balance sheet business, and financial market integration. They shift from asset management strategies to debt management strategies, resulting in greater risk to banks.

Market liberalization following the relaxation of regulation allows financial institutions to gain more space and more severe risks. Moral hazard, caused by lack of internal control and information asymmetry, forces financial institutions to adjust their strategies. Multi-level regulations are carried out on the market and the businesses of financial institutions. Kane and Cartalan, based on the history of financial regulation, verified the method of "regulation-relaxation-re-regulation"3-4. Sanders and Konnett proposed that the existence of financial institutions reduced the cost of market transactions and managed risk in a more efficient way ${ }^{4-5}$. Meanwhile, the occurrence of financial crisis implied the huge negative externalities of financial institutions, driving financial regulatory authorities to adopt more effective methods to manage risk. Chen argued that the risk framework of modern financial institution was made up of three mechanisms, that is, internal control, hedging, and economic capital, which effectively manage financial risks from the three perspectives of corporate governance, business, and institution.

\section{Overview of International Financial Risks}

\subsection{International Financial Risks}

The serious mistakes of the global financial regulatory system led to the U.S. financial crisis in 2008, which were major reasons for the global economic crisis. Financial regulatory competition resulted in the trend of relaxation of financial regulations worldwide. However, due to overly loose regulation, regulatory arbitrage will trigger systemic risk of the global finance system and financial crisis.

The measures employed by western developed countries are described as follows ${ }^{6-9}$ :

(1) Changing regulatory model to integrated regulation-from division to unity; problems of regulatory overlap and regulatory vacuum.

(2) Expanding the scope of regulation and implementing seamless regulation-e.g. hedge funds.

(3) Highlighting systemic risk regulation and maintaining financial stability and security-Risk spillovers and infections are the most typical characteristics of systemic risk.

(4) Strengthening international financial regulatory cooperation and improving crisis coping capacity-e.g. early warning mechanism.

\subsection{Basel Accord and Regulation}

The Second Basel Accord supplemented contents on market risk and required banks to raise their risk identification and avoidance capabilities. On the basis of the original capital and credit risk control, it included market and operational risk in the scope of capital constraints. In 1973, Black and Scholes proposed options pricing model, laying the quantitative theory and basis of modern financial risk and expanding financial institutions from traditional credit risk to market, interest rate, and exchange rate market. And methods like volatility analysis and Var risk value are used. Especially, Var has become one of the main methods to assess risk by financial institutions ${ }^{10-11}$.

In 1999, the United States issued Financial Services Modernization Law. It proposed functional regulation and penetrated financial regulation to each level of financial activities. From market to enterprise and to the development and transaction of financial products, comprehensive 
financial stability was sought after. The regulatory framework of the Second Basel Accord stressed the three pillars of financial regulation, namely, minimum capital adequacy ratio, external regulation, and market constraints. The Third Basel Accord made the definition of capital and the calculation method of risk-weighted asset stricter, substantially increased the requirements of the minimum capital adequacy ratio, and strengthened leverage and liquidity regulation ${ }^{13-14}$.

\subsection{Financial Regulatory Objectives}

The purpose of financial regulation is to reduce the risk of financial institutions and increase social benefits. Due to the desire for profits, financial institutions may seek high-risk premium through violations like regulatory arbitrage. In the context of financial liberalization and globalization, the efficiency of financial regulatory objectives had attracted considerable attentions. With the development of financial internationalization and the deepening of financial theories, financial objectives turn diversified. Kenneth Spong deemed that financial regulatory objectives could be studied from three aspects, namely, stability, efficiency, and equity, which are described below, respectively ${ }^{15-}$ 16 .

(1) Financial stability indicators mainly include capital adequacy ratio and non-performing assets rate. Domestic non-performing assets (NPAs) mainly refer to loan assets. Because of special national conditions, financial asset management companies are mostly established to divest assets, which, to some extent, distort market information and hides risks.

(2) Financial efficiency indicators mainly refer to the efficiency of banks and stock market. Stock trading/GDP is adopted to measure the degree of activity of stock trading in each region and reflect the degree of perfectness of financial system reform and efficiency of market distribution of a country.

(3) Financial equity objectives. Equity of financial regulation mainly reflects in the protection of depositors and investors, improvement of other credit systems, reduction of the moral hazard and adverse selection risk of credit systems, and, more importantly, the promotion of the development of financial system.

\section{Development of Chinese Financial Regulation}

\subsection{Development of Financial Regulation}

China mainly adopted planned economy. Banks belonged to the country. In the 1970s, it carried out financial system reform. The four major banks of "Industrial and Commercial Bank of China, The Agricultural Bank of China, Bank of China, and China Construction Bank" were separated from the central bank. China's secondary banking system was formed. People's Bank of China (PBOC) implemented government savings policies and integrated regulation and control. In the face of increasingly complex economic activities, it failed to carry out effective regulation. In 1998, the Securities Commission of the State Council was incorporated into China Securities Regulatory Commission to supervise securities market which was originally managed by PBOC. In November 1998, China Insurance Regulatory Commission (CIRC) conducted unified supervision of the insurance market. In April 2003, China Banking Regulatory Commission (CBRC) accepted the regulation and management of bank. PBOC takes charge to implement macro-monetary and fiscal policies and supervise market risk. Hence, the separated supervision system of "PBOC, CIRC, CBRC, and China Securities Regulatory Commission (CSRC)" had been set up $^{17-18}$.

At present, Chinese financial institutions, through financial innovation, avoid risks and supervision, but make limited achievements as subject to the market. With respect to financial products, cross-industry financial instruments, such as insurance loan and investment-linked insurance, begin to appear. Asset securitization preliminary runs in China. House mortgage and bank distressed debt has become the entry point of securitization. Nevertheless, overall speaking, there is a big gap between China and international standards in regard to the current framework and regulations of Chinese financial regulation and contents and means of risk management. Thus, the severe subprime mortgage crisis is worth of reflection ${ }^{18-19}$.

\subsection{Problems of Chinese Financial Regulation-System of PBOC, CIRC, CBRC, and CSRC}

(1) Mixed operation and obvious deficiencies in separated supervision-e.g. financial holding company.
(2) Fast financial innovation, narrow scope of supervision, and lack of effective supervision over mobile banking, online banking, hedge funds, and private equity funds.

(3) Increased systemic risk, weak financial regulation, and financial crisis show that systemic risk is the biggest risk for the financial stability of a country;

(4) International financial linkage, deepening of international market, and lack of financial regulatory cooperation mechanism.

\section{Conclusion}

In the context of integration of international risks, China is involved inevitably. Therefore, from macro and micro perspectives, it is extremely significant to comprehensively consider the development strategy of financial regulation in the future. Global financial regulatory arbitrage was one of the major external conditions for subprime mortgage crisis and European debt. Increase in regulatory arbitrage may allow some financial institutions to escape from the regulation of the society and regulatory authorities and conduct high-risk financial activities. The existence of differences in regulatory systems is a condition for regulatory arbitrage. Financial holding companies usually, through business transfer and financial innovation, avoid regulatory arbitrage.

\subsection{Suggestions on the Polices of Chinese Financial Regulation}

(1) Actively participating in international multilateral and regiona financial regulatory cooperation.

(2) Improving the environments for domestic financial regulation and international cooperation of financial regulation, introducing functional regulation in an appropriate time and establishing demandoriented supply system to address the problems of insufficient supply of market regulation like financial innovation and market constraints and excessive supply like market access and business operation.

(3) Strengthening the coordination between macro-prudential management and micro-prudential regulation, as well as regulation of systematic risk of cross-sectored financial cross-products.

(4) Improving the coordination mechanism of domestic financia regulation, enhancing the joint Meeting mechanism established among PBOC, CIRC, CBRC, and CSRC, setting up financial regulatory information sharing mechanism, realizing the coordination and cooperation among financial regulatory authorities, and implementing comprehensive and integrated risk management in combination of internal system control.

(5) Learning from foreign experience, improving the internal control system of financial institutions, protecting the interests of consumers, and establishing industry self-discipline organizations.

\subsection{Chinese Operational Strategies under the Third Basel Accord}

Chinese financial authorities shall, under the new regulatory framework determined by America, strongly advocate maximization of self-interest. First, close attention shall be paid to the spillover effects of major financial regulation of developed countries on China. For instance, the measures adopted by Europe and America to enhance the regulation of hedge funds, and the transfer of capital funds to emerging countries with loose regulation will lead to financial instability of the country or region. Thus, relevant regulations shall be quickly issued to cover regulatory gaps and loopholes. Second, China shall adapt to the current situation to promote and deepen its financial regulatory system reform. For example, regulatory institution like The Financial Stability Oversight Council of America can be formed to intervene in an appropriate time and achieve effective regulation before, during, and after financial matters.

\section{References}

[1] Wang, T., The U.S.-led Current International Financial Regulatory Framework: Evolution, Drawback, and Reconfiguration. Studies of International Finance, 2013(10).

[2] Lo, S. C., Evolution of Financial Regulatory System and Risk Management of Financial Institutions. Journal of Guangdong University of Finance, 2013(5).

[3] Chang, C. C. \& Li, C., Study on the Regulatory Arbitrage Theories in the Context of Unbalanced International Cooperation of Financial Regulation. Studies of International Finance, 2011(8). 
[4] Li, C., Li, Y. L., Wang, T., Empirical Analysis on the Goal Achievement of Financial Regulation from the Macro-prudential Perspective. Studies of International Finance, 2013(1).

[5] Chiu, L., \& Cheng, S. H., Global Financial System Reform and Chinese Financial Regulatory System Reform. Monthly Journal of Central University of Finance and Economics, 2011(9).

[6] Lee, Y.C., Chu, W.H., Chen, Q., Tsai, S.B., et al. 2016. Integrating DEMATEL Model and Failure Mode and Effects Analysis to Determine the Priority in Solving Production Problems. Advances in Mechanical Engineering, 1-12, 2016, 8(4).

[7] Tsai, S.B., Xue, Y., Zhang, J., Chen, Q., et al. 2016. Models for Forecasting Growth Trends in Renewable Energy. Renewable \& Sustainable Energy Reviews, 2016, DOI: 10.1016/j.rser.2016.06.001.

[8] Qu, Q., Chen, K.Y., Wei, Y.M., et al. 2015. Using Hybrid Model to Evaluate Performance of Innovation and Technology Professionals in Marine Logistics Industry Mathematical Problems in Engineering, Article ID 361275, http://dx.doi.org/10.1155/2015/361275(2016). p.8.

[9] Zhou, J. Wang, Q., Tsai, S.B., et al. 2016. How to Evaluate the Job Satisfaction of Development Personnel. IEEE Transactions On Systems Man Cybernetics-Systems,10.1109/TSMC.2016.2519860(2016).

[10] Su, J. M., Lee, S. C., Tsai, S. B. \& Lu, T. L. 2016. A comprehensive survey of the relationship between self efficacy and performance for the governmental auditors. Springer Plus, 5:508. DOI 10.1186/s40064-0162104-x(2016).

[11] Chen, H.M., Wu, C.H., Tsai, S.B., Yu, J., et al. 2016. Exploring key factors in online shopping with a hybrid model. Springer Plus, 5:2046. DOI 10.1186/s40064-016-3746-4(2016).
[12] Wang, J., Yang, J., Chen Q. \& Tsai, S.B. Collaborative Production Structure of Knowledge-sharing Behavior in Internet Communities. Mobile Information Systems, Article ID 8269474, 9 pages, http://dx.doi.org/10.1155/2016/8269474(2016).

[13] Wang, J., Yang, J., Chen Q. \& Tsai, S.B. Creating the Sustainable Conditions for Knowledge Information Sharing in Virtual Community. Springer Plus, 5:1019, DOI 10.1186/s40064-016-2702-7(2016).

[14] Lee, Y.C., Wang, Y.C., Chien, C.H., Wu, C.H., et al. 2016. Applying Revised Gap Analysis Model in Measuring Hotel Service Quality, Springer Plus, 5:1191, DOI 10.1186/s40064-016-2823-z.

[15] Lee, Y.C., Wang, Y.C., Lu, S.C., Hsieh, Y.F., et al. An Empirical Research on Customer Satisfaction Study: A Consideration of Different Levels of Performance. Springer Plus, 5:1577, DOI 10.1186/s40064-016-3208$\mathrm{z}(2016)$.

[16] Chin, T., Tsai, S.B., Fang, K., Zhu, W., et al. 2016. EO-Performance relationships in Reverse Internationalization by Chinese Global Startup OEMs: Social Networks and Strategic Flexibility. PLoS ONE, 11(9): e0162175, doi:10.1371/journal.pone.0162175.

[17] Lee, S.C., Su, J.M., Tsai, S.B., Lu, T.L., et al. A comprehensive survey of government auditors' self efficacy and professional Development for improving audit quality. Springer Plus, 5:1263, DOI 10.1186/s40064-0162903-0(2016).

[18] Chen, H.M., Wu, C.H., Tsai, S.B., Yu, J., et al. 2016. Exploring key factors in online shopping with a hybrid model. Springer Plus, 5:2046, DOI 10.1186/s40064-016-3746-4.

[19] Ge, B., Jiang, D., GAO, Y., \& Tsai, S.B. 2016. The Influence of Legitimacy on a Proactive Green Orientation and Green Performance: A Study Based on Transitional Economy Scenarios in China. Sustainability, 8, 1344, 1-20. Doi: $10.3390 /$ su8121344. 